Proc. Indian Acad, Sci. (Egrth Plaze1. Sci.), Volo 91, No. 1, March 1982, pp. 65-73. (C) Printed in India.

\title{
Rb-Sr age of Gaik granite, Ladakh batholith, northwest Himalaya
}

\author{
J R TRIVEDI, K GOPALAN, KEWAL K SHARMA*, \\ K R GUPTA* and Y M CHOUBEY* \\ Physical Research Laboratory, Ahmedabad 380009 , India \\ *Wadia Institute of Himalayan Geology, Dehra Dun 248001 , Indja
}

MS received 25 August 1981 ; jrevised 19 December 1981.

\begin{abstract}
The Gaik Granite is a part of the Ladakh batholith outcropping between Gaik and Kiari in NW Himalaya. This is a pink porphyritic granite rich in biotite and poor in homblende. Rb-Sr analyses have been made on six whole-rock samples of the Gaik Granite. Though the samples are poorly enriched in radiogenic $\mathrm{Sr}$, they define a reliable isoctron corresponding to an age of $235 \pm 13(2 \sigma) \mathrm{m}$.y. and initial ${ }^{87} \mathrm{Sr} /{ }^{86} \mathrm{Sr}$ ratio of $0.7081 \pm 0.0004(20)$. Biotite, plagioclase and potash feldspar fractions separated from two of the samples have yielded a much younger mineral isochron at $30 \pm 1.5 \mathrm{~m} . \mathrm{y}$. indicating a nearly complete redistribution of $\mathrm{Sr}$ isotopes between mineral phases at a time much later than the primary emplacement of the granite. The present results show that at least some components of the Ladakh batholith are of Permo-Triassic age. These tocks were isotopically re-equilibrated on a mineral seale during Upper Oligocene in response to the Himalayan orogeny.
\end{abstract}

Keywords. Rb-Sr age; isochron; Ladakh batholith; Hercynian; Permo-Triassic; granite.

\section{Introdaction}

The Ladakh batholith which occurs as a linear body measuring about $600 \mathrm{~km}$ long and $25-75 \mathrm{~km}$ wide and covers a major part of the Ladakh range in the Transhima* layan region has attracted the attention of geoscientists all over the world. In recent years, many attempts have been made to understand the nature, tectonic setting and the age of this batholith. The present paper deals with the $\mathrm{Rb}-\mathrm{Sr}$ age of a distinct plutonic body of the pink porphyritic granite exposed between Gaik and Kiari (figure 1).

\section{Geologic setting}

The various aspects of the geology of the Ladakh region, including the Ladakh batholith, have been receiving attention of the geologists for more than a century now (Stoliczka 1866; Oldham 1888; McMahon 1901; De Terra 1932, 1935; Auden 1935; Berthelsen 1953; Tewari 1964; Gupta and Kumar 1975; Raiverman and Misra 1975; Shah et al 1976; Frank et al (1977; Fuchs 1977; Sharma and Gupta 1978; Pal et al 1978; Srikantia and Razdan 1980 and Thakur et al 1981). Recently, Sharma (1981) highlighted a few new features of the Ladakh-Deosai batholith (commonly 


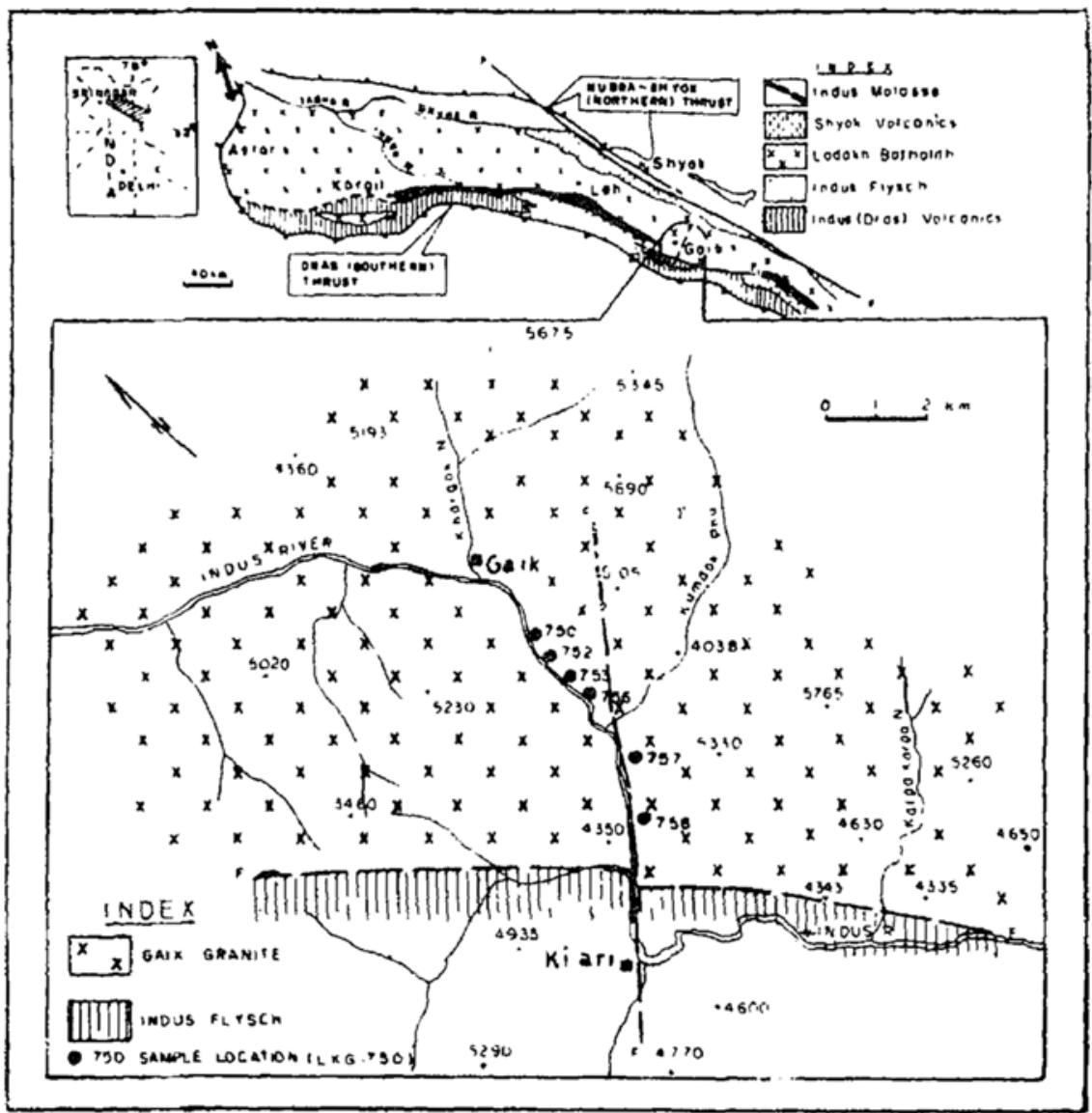

Figure 1. Simplified geological map of the Gaik Granite and vicinity with sample locations shown by black dots with accompanying Jabel.

called Ladakh batholith) and its surrounding rocks along with a critical discussion of the existing beliefs on its age. Only a brief geological account is given below.

The rocks of the Indus Suture Zone are separated from the Crystallines and the Tethyan rocks of the Himalayan region by a south dipping thrust commonly known as the Dras thrust. The Indus Suture zone rocks are largely shale and graywacke with turbidite structures, radiolarian chert, jasperoid shale, conglomerates and occasional limestone varying in age from Lower Cretaceous to Lower Palaeogene. A thick pile of basic to intermediate volcanics with associated ophiolitic melange is very well exposed around Dras in the northwest and Sumdo in the southeast of this zone whereas in between these two areas it is reduced to thin slices due to thrusting. The Ladakh batholith which lies to the north has an intrusive relationship with the Dras Volcanics near Burzil (Wadia 1937) and Kargil-Batalik area (Sharma 1981) and a tectonic relationship with the rocks of the Indus Flysch between Kiari and Chumathang. At other places the southern contact of the Ladakh batholith is covered 
Table 1. Major litho-tectonic units of Ladakh region from south to north

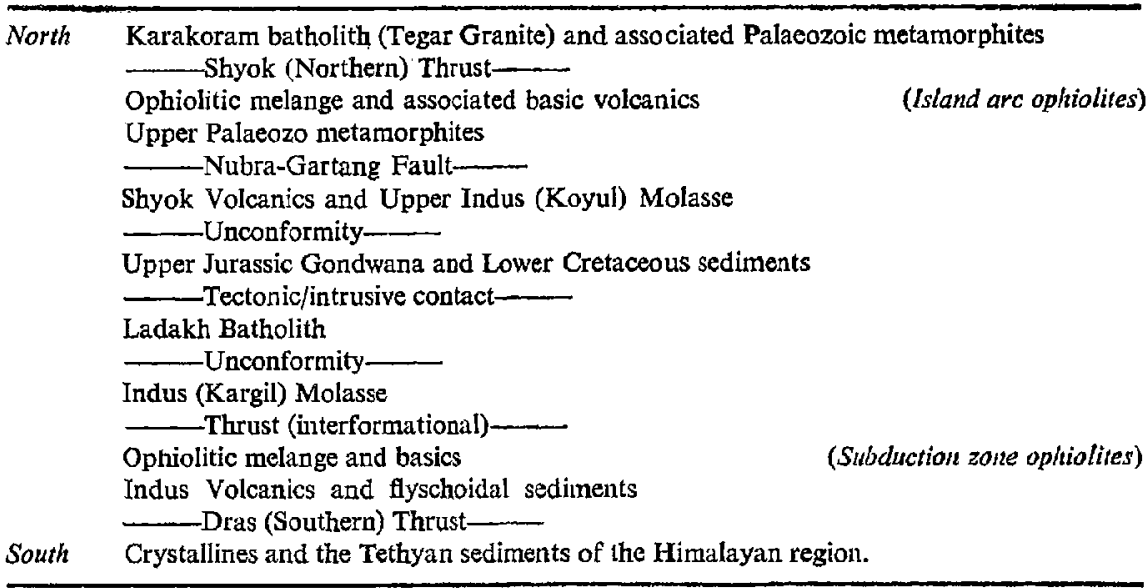

under a linear belt of the Indus Molasse of Miocene-Pliocene (?) age. The various litho-tectonic units exposed from south to north as reported by Sharma and Gupta (1981) are given in table 1.

As shown in figure 1 and table 1 the northern margin of the Ladakh batholith is covered by the Shyok volcanics of the early Cenozoic period, which are acid to intermediate (calc-alkaline) in composition (Sharma and Gupta 1981).

The Ladakh batholith is composed chiefly of quartz bearing rocks that vary widely in composition from quattz diorite, granodiorite, quartz- monzodiorite, quartz monzonite to granite with occasional masses of diorite, gabbro, pyroxenite and anorthosite. This batholith is a complex body composed of a large number of plutons of different composition and character which can be readily distinguished from one another in the field by differences in mineral composition and texture as is evident in the Gaik-Kiari and Hanuthang sections (Sharma 1981). An E-W trending fault in the Upshi-Kari section has uplifted the rocks from the deeper levels of the Ladakh batholith and the deep gorge of the Indus river has exposed them for a direct observation. One can study the best development of a pink porphyritic granite body between Kiari and Gaik. Tongues and apophyses of leucogranite, a few tens of metres across, cut through the pink porphyritic granite towards its margin near Gaik. An extensive body of the leucogranite is exposed between Tirdo and Lickhe with occasional relicts of the pink porphyritic granite in it. It is interesting that the pink porphyritic granite and the leucogranite exposed in this section are either free from hornblende or very poor in it and thus differ from the hornblende granite, extensively developed in other parts of the Ladakh batholith.

\section{Previous age data}

The age of Ladakh Granite has been discussed by various workers mostly on the basis of the field relations. Stoliczka (1874) considered the Ladakh gneiss to be of Silurian age, whereas Lydekker (1880) compared it with 'Central Gneiss'. Auden (1935) E.P.S. -5 
and Wadia (1937) on the basis of their observations in the Skardu-Satpura and AstorBurzil areas respectively consider the hornblende granite to be Tertiary, as it intrudes into the volcanics and limestones containing Upper Cretaceous-Eocene fossils. Auden (1935) also observed that the biotite granite into which the hornblende granite intrudes near Shyok-Indus confluence may be of an earlier age i.e. Hercynian, Caledonian, or even Precambrian. De Terra (1932) and Dainelli (1933-34) also assigned Hercynian age to this granite.

In recent years considerable interest has been shown by the geoscientists for a better understanding of the geology of the Ladakh region as it is believed to be the zone of plate-to-plate collision (Gansser 1964). The age of the Ladakh batholith which plays a crucial role in the palaeogeographic and palaeotectonic reconstruction of this region is still controversial. Shankar et al (1976 a, b), Shah et al (1976), Srikantia and Bhargava (1978), Pal et al (1978), Srikantia and Razdan (1980) consider the major part of the Ladakh batholith to be pre-Upper Cretaceous in age, and a few of them also believe that in the late Tertiary times widespread acid igneous activity resulted in the formation of the Kargil granite (Shah et al 1976; Varadarajan et al 1980); Chumathang-Kiari granite, pegmatite, aplites, quartz and quartz-fluorite veins (Shanker et al $1976 \mathrm{a}, \mathrm{b}$; Srikantia and Bhargava, 1978). These authors based their views on the limited area of their study without a serious consideration of the radiometric age data on Ladakh granites. However, Desio et al (1964) reported a model Rb-Sr age of $48 \mathrm{~m} . y$. for the granodiorite from Satpura, South of Skardu and Desio and Zanettin (1970) dated a granite boulder of the Hemis conglomerate as $38 \mathrm{~m} . \mathrm{y}$. Both these ages point to post-Upper Cretaceous age of the Ladakh batholith as believed by Wadia (1937), Frank et al (1977), Rai and Pande (1978) and Sharma and Kumar (1978). Sharma et al (1978) also reported K-Ar age of $28 \pm 1 \mathrm{~m} . \mathrm{y}$. for the pink-porphyritic granite from Hemiya in the Upshi-Kiari Section. Recently, Sharma et al (1981) reported the fission track ages of sphene and apatite from different parts of the Ladakh batholith. The age of sphene varies from 25 to $34 \mathrm{~m} . \mathrm{y}$. and that of the apatite from 12 to $25 \mathrm{~m} . \mathrm{y}$. Although the $\mathrm{K}-\mathrm{Ar}$ and fission track age data indicate only the cooling ages since the last thermal event, this data lend some support to the $\mathrm{Rb}-\mathrm{Sr}$ ages reported by Desio et al (1964) and Desio and Zenettin (1970) from other parts of the Ladakh batholith. The field evidences and the limited radiometric age data so far available on the Ladakh batholith suggest that a major part of the Ladakh batholith is post-Upper Cret_ceous.

\section{Analytical procedure}

The locations of the samples taken for analysis are shown in figure 1 and their petrographic descriptions given in appendix. Mass spectrometric analyses for $\mathrm{Rb}$ and $\mathrm{Sr}$ in the whole rocks were carried out on about 0.2 to $0.3 \mathrm{gm}$ of finely powdered and well-homogenized samples prepared from whole-rock specimens weighing 12-15 $\mathrm{kg}$. The crushing and grinding of the samples were carried out using a jaw crusher, disc grinder and Tema-Mill which were mechanically cleaned between the samples and preconditioned with a small portion of the sample under processing to minimise cross-contamination.

Various mineral fractions used for the analysis were separated with a magnetic separator and organic heavy liquids. 
Total $\mathrm{Rb}$ and $\mathrm{Sr}$ contaminations from the reagents and chemical procedure were measured by periodically running blanks in parallel with the samples. The blank levels are usually $0.006 \mu \mathrm{g}$ for $\mathrm{Rb}$ and $0.008 \mu \mathrm{g}$ for $\mathrm{Sr}$, which introduce negligible error $(<0.15 \%)$ in the amount of $\mathrm{Rb}$ and $\mathrm{Sr}$ normally handled. The samples were run on a $23 \mathrm{~cm}, 60^{\circ}$ sector, single focussing, mass spectrometer fitted with a Faraday cup collector. The peak heights were registered on a chart recorder. ${ }^{87} \mathrm{Rb}$ and ${ }^{84} \mathrm{Sr}$ spikes were used for isotope dilution analysis and the data were normalized to an assumed natural value of $\mathrm{Sr}^{86} / \mathrm{Sr}^{88}=0.1194$. The uncertainty in ${ }^{87} \mathrm{Rb} /{ }^{86} \mathrm{Sr}$ ratio is about $2 \%$ and in ${ }^{87} \mathrm{Sr} /{ }^{86} \mathrm{Sr}$ ratio is the standard deviation of a set of 10 peak height comparisons.

\section{Results and discussion}

The $\mathrm{Rb}-\mathrm{Sr}$ data for the six whole-rock samples and mineral fractions separated from two of them are given in table 2. Individual sets of data are plotted on separate $\mathrm{Rb}$ $\mathrm{Sr}$ isochron diagrams, with the straight line shown in each being the least squares fit of the data based on the two error weighed regression of York (1966). Figure 2 shows the jsochron for six whole-rocks samples of the Gaik Granite. All the samples conform to a linear array within experimental error. The slope of this line gives the age of the Gaik Granite as $235 \pm 13 \mathrm{~m} . \mathrm{y}$. (20) and its $Y$-intercept the initial ${ }^{87} \mathrm{Sr} /{ }^{80} \mathrm{Sr}$ ratio as $0.7081 \pm 0.0004(2 \sigma)$ assuming the ${ }^{87} \mathrm{Rb}$ decay constant as $1.39 \times 10^{-11} \mathrm{yr}^{-1}$. The low initial $\mathrm{Sr}$ ratio of the Gaik Granite is typical of Rb-poor sources implying a deep crustal origin with negligible contamination with crustal material.

Mineral isochrons for the two whole-rock samples LKG-752 and LKG-753 are shown in figures 3 and 4 . The two mineral ages are concordant at $30 \pm 1.5 \mathrm{~m} . \mathrm{y}$. and $29 \pm 1.5 \mathrm{~m} . \mathrm{y}$., respectively. The minerals in sample LKG-753 have experienced a more complete reequilibration of their Sr-isotopes than the minerals in LKG-752.

Table 2. Analytical results

\begin{tabular}{|c|c|c|c|c|}
\hline Sample & $\begin{array}{c}{ }^{87} \mathrm{Rb} \\
(\mathrm{ppm})\end{array}$ & $\begin{array}{c}{ }^{80} \mathrm{Sr} \\
(\mathrm{ppm})\end{array}$ & $\begin{array}{l}{ }^{87} \mathrm{Rb} /{ }^{88} \mathrm{Sr} \\
\text { (atomic) }\end{array}$ & $\begin{array}{l}{ }^{87} \mathrm{Sr} /{ }^{86} \mathrm{Sr} \\
\text { (atomic) }\end{array}$ \\
\hline LKG 750 WR & $60 \cdot 24$ & $89 \cdot 38$ & 0.67 & $0.7107 \pm 0.0009$ \\
\hline LKG 752 WR & $70 \cdot 76$ & $50 \cdot 98$ & $1 \cdot 37$ & $0.7122 \pm 0.0009$ \\
\hline LKG 752 BIO-I & 376.77 & $2 \cdot 31$ & $161 \cdot 23$ & $0.7791 \pm 0.0010$ \\
\hline LKG 752 BIO-II & $331 \cdot 32$ & $7 \cdot 12$ & 46.00 & $0.7318 \pm 0.0020$ \\
\hline LKG $752 \mathrm{KF}$ & $113 \cdot 09$ & $59 \cdot 46$ & 1.88 & $0.7153 \pm 0.0008$ \\
\hline LKG 752 PIAG & $8 \cdot 6$ & $49 \cdot 28$ & 0.17 & $0.7094 \pm 0.0015$ \\
\hline LKG 753 WR & $108 \cdot 28$ & $15 \cdot 70$ & 6.82 & $0.7307 \pm 0.0014$ \\
\hline LKG 753 BIO-I & $518 \cdot 8$ & $1 \cdot 264$ & $405 \cdot 72$ & $0.8774 \pm 0.0011$ \\
\hline LKG 753 BIO-II & 513.71 & 0.638 & $795 \cdot 9$ & $1 \cdot 0563$ 上 0.0020 \\
\hline LKG $753 \mathrm{KF}$ & $173 \cdot 77$ & $19 \cdot 79$ & $8 \cdot 7$ & $0.7315 \pm 0.0016$ \\
\hline LKG 753 PLAG & $8 \cdot 54$ & $9 \cdot 22$ & 0.92 & $0.7275 \pm 0.0012$ \\
\hline LKG 756 WR & 58.67 & $96 \cdot 41$ & 0.60 & $0.7102 \pm 0.0010$ \\
\hline LKG $757 \mathrm{WR}$ & 57.98 & $87 \cdot 12$ & 0.66 & $0.7104 \pm 0.0009$ \\
\hline LKG $758 \mathrm{WR}$ & $72 \cdot 80$ & $46 \cdot 33$ & $1 \cdot 55$ & $0.7128 \pm 0.0011$ \\
\hline
\end{tabular}




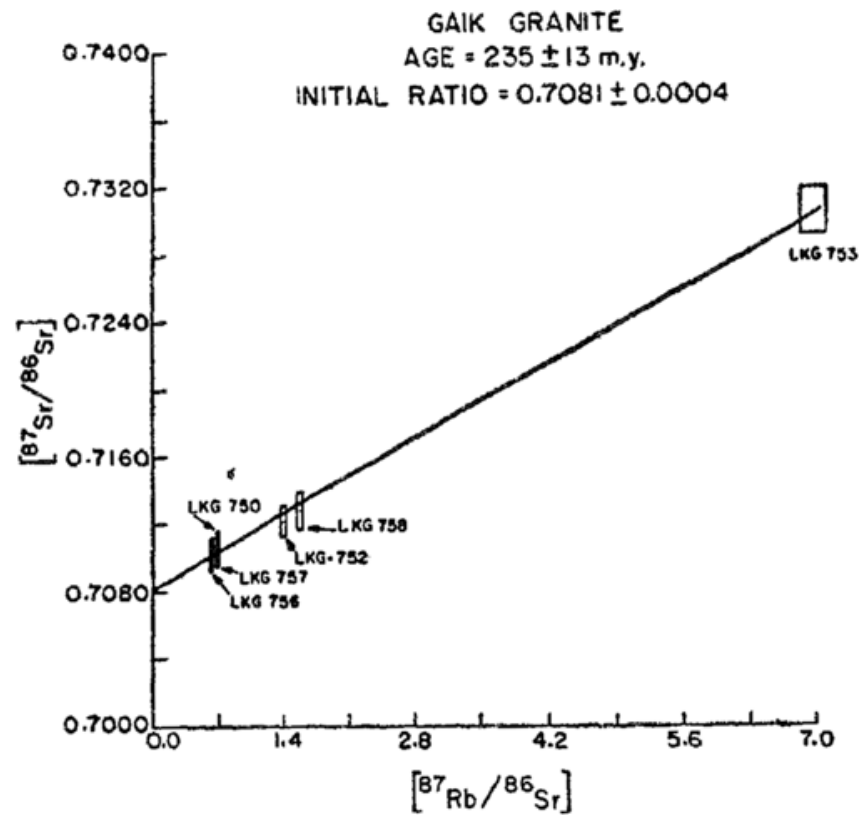

Figure 2. Rb-Sr isochron diagram for the whole rock samples of the Gaik Granite.

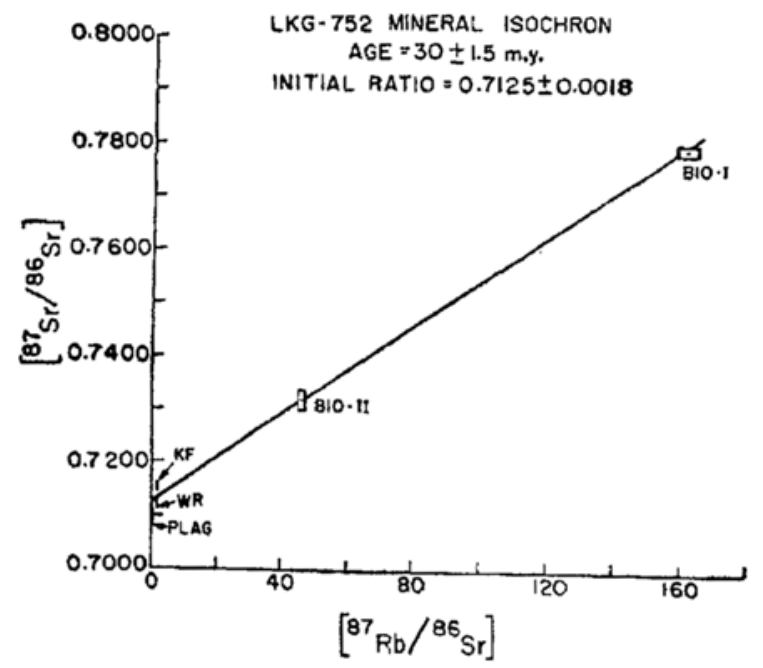

Figure 3. Rb-Sr isochron diagram for minerals separated from rock sample LKG-752.

This reequilibration between mineral phases is presumably due to a thermal event suffered by the Gaik Granite during the Upper Oligocene times.

The foregoing results clearly show that the pink porphyritic granite exposed between Gaik and Kiari is Permo-Triassic in age. This magmatic activity is possibly correlatable with the waning phase of the Hercynian Orogeny. This granitic body 


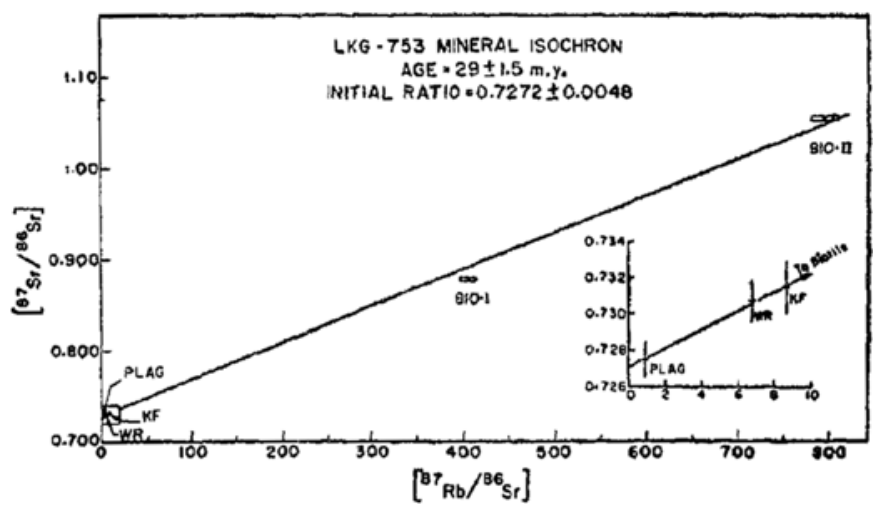

Figure 4. Rb-Sr isochron diagram for minerals separated from rock sample LKG-753.

was subsequently involved in a thermal episode presumably during the period of large scale magmatism in the Indus Suture Zone, which reequilibrated the strontium istopes between its mineral phases about $30 \mathrm{~m} . y$. ago. Such a thermal event on rocks between Likche and Kiari during Upper Oligocene is also indicated by the K-Ar age of $28+1$ m.y. for the pink porphyritic granite from Hemiya and fission track age of sphene from this area (Sharma et al., 1978, 1981).

The present data is not adequate to resolve the controversy about the age of the Ladakh batholith as a whole. However, it does suggest that the Ladakh batholith is a complex granitoid body and some components of this may be as old as PermoTriassic. The mineral isochron age of $30 \mathrm{~m} . \mathrm{y}$, for the Gaik Granite and the model $\mathrm{Rb}-\mathrm{Sr}$ age of $48 \mathrm{~m} . \mathrm{y}$. for the granodiorite from Skardu (Desio et al 1964) bear evidence that a large scale plutonic activity in the early Tertiary time played a major role in the evolution of the Ladakh batholith. The detailed radiometric study of the Ladakh batholith, in progress, would lead to a better understanding the temporal evolution of this batholith.

\section{Acknowledgements}

The authors thank Professor D Lal, Dr SCD Sah for the encouragement and facilities to carry out this collaborative study, and Professor S N Sarkar for critical reading of the manuscript.

\section{References}

Auden J B 1935 Rec. Geol. Surv. India 69 (2) 125

Berthelsen A 1953 Modd. Fra. Geologisk Forening 12 (3) 351

Dainelli 1933-1934 Relaz. Scient. Spediz. De Filippi 11 (2)

Desio A, Tongiorgi E and Ferrara. G 1964 Proc. 22nd Int. Geol. Congr. 2479

Desio A and Zanettin B 1970 Geolegy of Baltoro basin III-Geology and Petrology II Italian expedition.

De Terra H 1932 Wissensch. Ergebn, d. Dr. Zentralasien Expedition Berlin 2 1-114

De Terra H 1935 Mern. Connecticut Aged. Arts Sci. 8 (2) 18 
Frank W, Ganssei A and Trommsdorff V 1977 Schweiz. Mineral Petrgr. Mitt. 5789

Fuchs G $1977 \mathrm{Jb}$. Geol. B.-A 120 (2) 219

Gansser A 1964 Geology of the Himalayas (London: Interscience) 1

Gupta V J and Kumar S 1975 Sonderdruckausder Geologischen Rundschau 64

Lydekker 1880 Rec. Geol. Surv. India 3 (1) 121

McMahon C A 1901 Mem. Geol. Surv. India 31 (3) 303

Oldham R D 1888 Rec. Geol. Surv. India 21 (4) 149

Pal D, Stivastaya R A K and Mathur N S 1978 Him. Geol. 8 (1) 500

Rai $\mathrm{H}$ and Pande $\mathrm{I} C 1978$ Recent researches in geology 5 (Delhi: Hindustan Publishing Co.)

Raiverman V.and Misra V. N 1975 Geol. Min. Met. Soc. Indir Bull. 481

Shah S K, Sharma M L, Gergan J T and Tara C S 1976 Him. Geol. 6534

Shankar R, Padhi R N, Prakash G, Thussu J L and Das R N 1976a Him. Gcol. Seminar, New Delhi

Shankar R, Padhi R N, Prakash G, Thussu J L and Wangdus C 1976b Geol. Surl. India Misc. Pub. 34 (1) 41

Sharma K K 1981 Him. Geol. 2 (In press)

Sharma K K and Gupta K R 1978 Recent researches in geology 7 (Delhi: Hindusthan-Publishing Corp.) p. 133

Sharma K K and Gupta K R 1981 Him. Geol. 2 (In press)

Sharma K K and Kumar S 1978 Him. Geol. 8 (1) 252

Sharma O P, Sharma K K and Nagpaul K K 1981 Fission Track Workshop Aimedabad

Sharma K K, Sinha A K, Bagdassarian G P, Gaukasian R C H 1978 Him. Geol. 8 (1) 288

Srikantia S V and Bhargava O N 1978 Tectonic geology of the Himaloya (ed) P S Saklani (New Delhi : Today and Tomorrow's Printers and Publishers) p. 43

Srikantia S V and Razdan M L 1980 J. Geol. Soc. India 11523

Stoliczka A 1866 Mem. Geol. Surv. India 5 (1) 1

Stoliczka A 1874 Rec. Geol. Surv. India 7 (1) 12

Tewari A P 1964 Proc. 22nd Int. Geol. Congr. 1137

Thakur Y C, Virdi N S, Rai H and Gupta K R $1981 \mathrm{~J}$. Geol. Soc. India 22 (1) 46

Varadarajan S, Uppal U S and Vashist N 1980 Proc. 3rd Indian Geol. Congr. Poona 46I

Wadia D N 1937 Rec. Geol, Surv. India 72 (2) 151

York D 1966 Can.J. Phys. 441079

\section{Appendix}

Brief description of the samples analysed

Specimen No. Description

LKG-750 Leucocratic, coarse grained, porphyritic granite with phenocrysts of pink to cream coloured feldspar, showing crude foliation and enrichment in biotite. It shows hypidiomorphic granular texture and is composed of $22.5 \%$ quartz, 34\% $\mathrm{K}$-feldspar (orthoclase and perthite), $33 \%$ plagioclase, $8.5 \%$ biotite and $2 \%$ accessories (sphene, titano-magnetite, apatite, zircon).

LKG-752 Coarse grained, porphyritic granite with cream to pink coloured feldspar, enriched in biotite and show crude foliation. It is composed of $27 \%$ quartz, $46 \% \mathrm{~K}$-feldspar (perthite, orthoclase), $22 \%$ plagioclase, $4 \%$ biotite and $1 \%$ accessories (apatite, zircon and titano-magnetite). 
Appendix (Contd)

Specimen No.

Description

LKG-753 It is medium to fine grained massive pepper and salt coloured granite. It is composed of $27 \%$ quartz, $41 \% \mathrm{~K}$-feldspar, $25 \%$ plagioclase, $5 \%$ biotite and $2 \%$ accessories.

LKG-756 Coarse grained, porphyritic granite containing $25 \%$ quartz, $35 \%$ K-feldspar, $30 \%$ plagio-clase, $8 \%$ biotite and $2 \%$ accessories (apatite, zircon and titano-magnetite).

LKG-757 Coarse grained foliated, gneissose granite rich in biotite. It is composed of $22 \%$ quartz, $27 \% \mathrm{~K}$-feldspar, $40 \%$ plagioclase, $8 \%$ biotite and $3 \%$ accessories (sphene, magnetite, zircon, apatite and rutile). The minerals in general, show strain effects.

LKG-758 Coarse grained granite with crude foliation. It is composed of $25 \%$ quartz, $40 \% \mathrm{~K}$-feldspar (orthoclase, microcline, perthite), $25 \%$ plagio-clase, $8 \%$ biotite and $2 \%$ accessories (apatite, sphene and titano-magnetite). The minerals show strain effects. 